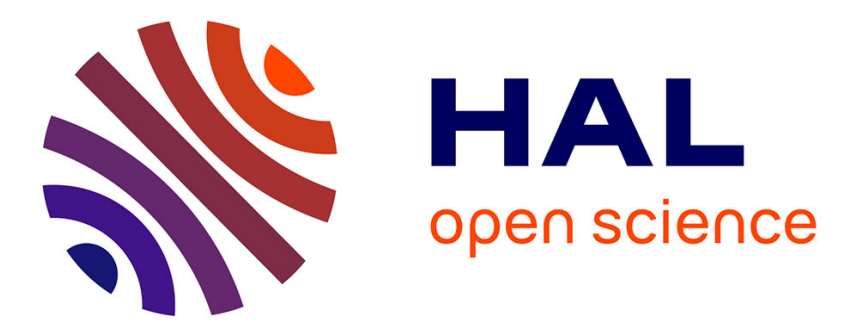

\title{
Medial thighplasty after massive weight loss: are there any risk factors for postoperative complications?
}

Nicolas Bertheuil, Sophie Thienot, Vincent Huguier, Cédric Ménard, Eric Watier

\section{- To cite this version:}

Nicolas Bertheuil, Sophie Thienot, Vincent Huguier, Cédric Ménard, Eric Watier. Medial thighplasty after massive weight loss: are there any risk factors for postoperative complications?. Aesthetic Plastic Surgery, 2014, 38 (1), pp.63-8. 10.1007/s00266-013-0245-7 . hal-01010773

HAL Id: hal-01010773 https://hal-univ-rennes1.archives-ouvertes.fr/hal-01010773

Submitted on 18 Dec 2015

HAL is a multi-disciplinary open access archive for the deposit and dissemination of scientific research documents, whether they are published or not. The documents may come from teaching and research institutions in France or abroad, or from public or private research centers.
L'archive ouverte pluridisciplinaire $\mathbf{H A L}$, est destinée au dépôt et à la diffusion de documents scientifiques de niveau recherche, publiés ou non, émanant des établissements d'enseignement et de recherche français ou étrangers, des laboratoires publics ou privés. 


\section{Medial Thighplasty After Massive Weight Loss: Are There Any Risk Factors for Postoperative Complications?}

Nicolas Bertheuil* (1) (2) (3) Sophie Thienot ${ }^{(1)}$ Vincent Huguier $^{(4)}$ Cédric Ménard ${ }^{(2)}{ }^{(3)}$ Eric Watier $^{(1)}$

1. Department of Plastic, Reconstructive, and Aesthetic Surgery, Hospital Sud, University of Rennes 1, 16 Boulevard de Bulgarie, 35200, Rennes, France

2. INSERM U917, University of Rennes 1, Rennes, France

3. SITI Laboratory, Etablissement Français du Sang Bretagne, Rennes University Hospital, Rennes, France

4. Department of Plastic, Reconstructive, and Aesthetic Surgery, Poitiers University Hospital, Poitiers, France

\section{Abstract \\ Background}

With the increasing incidence of obesity in western societies, more and more patients undergo bariatric surgery that leads to functional and aesthetic sequelae related to a rapid and massive weight loss, namely skin and fat excess. The goal of surgical management after massive weight loss is to optimize the functional results obtained from bariatric surgery or diet with removal of the redundant skin folds. We report our experience with medial thighplasty following massive weight loss and identify predictive factors of postoperative complications.

Methods

This is a retrospective study of 53 patients operated for medial thighplasty after massive weight loss. Data were collected through chart review and Submitted to statistical analysis.

Results

The average weight loss before thighplasty was $43.5( \pm 14.9) \mathrm{kg}, 39.6 \%$ of patients experienced at least 1 complication. Complication rates were as follows: seroma 9.4\%, wound 
dehiscence $20.8 \%$, scar migration $17 \%$, wound infection $5.7 \%$ and partial skin necrosis $1.9 \%$. Pre-massive weight loss body mass index (BMI) and pre-medial thighplasty BMI were found to be risk factors for developing a postoperative complication.

Conclusion

Few guidelines exist on the optimization of care and safety in this complex patient population. The informations provided herein by this retrospective study complement the current data of the literature and can help surgeons to select patients eligible for medial thighplasty. We show that pre-medial thighplasty BMI should be taken into consideration for patients willing to go on body contouring procedure.

Evidence Based Medicine Level III: Evidence obtained from well-designed cohort or casecontrol analytic studies, preferably from more than one center or research group.

\section{Introduction}

Obesity is a major health risk factor because of associated medical complications such as cardiovascular disease, hyperlipidemia, diabetes, high blood pressure, cancer, degenerative arthritis and sleep apnea [1-4]. Obesity is a multifactorial disease whose one of the components seems to be from genetic origin. Several studies have identified genetic polymorphisms associated with obesity [5-8]. Others have been involved in the progression of obesity such as environmental and behavioural factors and socio-economic status [9].

Obesity may lead to difficulties in daily life (clothing, walking, sexual activity, hygiene problems), altering the quality of life and generating psychological disorders such as devalued self-image and depression. Bariatric surgery was developed to combat against obesity and is indicated for patients with a body mass index (BMI) $\geq 40 \mathrm{~kg} / \mathrm{m}^{2}$ or BMI $\geq 35 \mathrm{~kg} / \mathrm{m}^{2}$ with an 
additional related disease and an acceptable surgical risk [10]. With the increasing incidence of obesity in western societies, more and more patients undergo this type of surgery that leads to functional and aesthetic sequelae related to a rapid and massive weight loss, namely skin excess and poor skin tone. The goal of surgical management after massive weight loss is to optimize the functional outcomes obtained from bariatric surgery or diet with surgical removal of the redundant skin folds.

Within this field, the medial thighplasty is now well acknowledged. This kind of surgery was first described by Lewis et al in 1957 [11,12] and allows to reduce redundant skin and fat inside the thighs. Minor complications often occur such as scar enlargement, scar migration, recurrence of ptosis and vulvar problems [13]. However, improvements were made to the initial technique [14-16] by anchoring the superficial fascial layer to the Colles' fascia as described by Lockwood et al which has allowed to significantly reduce the number of cases of ptosis [17].

Two types of incision may be done depending on the location of the skin fold [18]: a horizontal approach for the excess on the upper third of the thigh or a vertical approach in case of important excess particularly after massive weight loss [19,20]. Over the past decade, liposuction has been more and more often combined to medial thighplasty in order to eliminate the fat excess to such and extent that it is now often the first step of the thigh lift. Concomitant liposuction has the advantage of improving the aesthetic results of the intervention, and reduces the healthcare cost by combining two operations into one. But this technique is regarded by some as risky as it may lead to ischemia and necrosis of the flaps.

There are presently few reports on the postoperative complications of medial thighplasty after massive weight loss. It seems necessary to improve the knowledge about this technique in order to have a better management of patients. 
The aim of our retrospective study, including 53 patients, was to report our experience with medial thighplasty following massive weight loss and identify factors predictive of postoperative complications.

\section{Materials and methods}

We report the experience of the Department of Plastic Surgery of Rennes University Hospital through a retrospective clinical study of 53 patients operated for medial thighplasty consecutively between September 2004 and December 2011. All of the patients who underwent a medial thighplasty were included. Data collection was done through analysis of medical records for each patient, including age, sex, weight and height, pre-bariatric surgery body mass index (BMI), pre-medial thighplasty BMI and weight loss before thighplasty. History of bariatric surgery was sought as well as diabetes, high blood pressure and osteoarthritis. Data regarding surgery included the type of medial thighplasty (horizontal or vertical incision), the use of liposuction, the pannus weight, operating duration, postoperative drainage duration, postoperative complications and duration of hospital stay. All operated patients had their weight stabilized at a plateau over a period of at least 6 months. Active smokers were asked to stop smoking for 1 month before the reconstructive procedure and for 1 month postoperatively.

This study has been performed in accordance with the principles of the Declaration of Helsinki (1964) and was in agreement with French bioethics laws of 7 july 2011.

\section{Operative procedure}


Drawings were made preoperatively in the standing and prone position with lower extremities in abduction. The superior incision is marked in the perineal-thigh fold. The anterior extent of the incision was stopped just before to the femoral triangle. The posterior extent continues into the medial buttocks fold. The location of excessive skin and fat is determined that allows to choose between horizontal scar $(n=50)$ or a combinaison of horizontal and vertical scar $(n=3)$. Then, we identify the point of maximum resection by pinching the skin. This point was marked. Then we drew an ellipse between this point and the anterior and posterior end of the drawing. Finally, suction areas are identified and marked.

Surgery was performed under general anesthesia and the patient was set up in the supine position combined with gynecological position. We performed an infiltration by lidocaineadrenaline to reduce bleeding during surgery and to facilitate liposuction. Liposuction, was always performed as the first step of surgical procedure, with the use of 3 or 4 mm-diameter cannulas. Liposuction was performed all along the thigh under the superficial fascial layer, and in addition under the skin pattern where all the fat under the dermis were eliminated. Then, the incision was lead until the Colles' fascia. We realized the removal of excess skin "on demand" as previously described [16]. The anchoring was performed with non-absorbable stitches beetween superficial fascial layer and Colles's fascia, then subcutaneous/sub-dermal planes were sutured with absorbable stitches (Monocryl ${ }^{\circledR} 3.0$ and 4.0). In all cases, suction drains were placed and skin closure was subsequently achieved without tension. An adhesive occlusive dressing (OpSite $\left.{ }^{\circledR}\right)$ was placed to prevent any contamination. Finally, compressive clothing (Lipo-Panty ${ }^{\circledR}$ standard S001 Medical Z) had to be worn for one month postoperatively.

\section{Postoperative care}


In all patients, phlebitis was prevented by the subcutaneous administration of low molecular weight heparin (Lovenox ${ }^{\circledR}$ ) for a period of 10 days postoperatively and wearing compressive stockings for a period of 15 days. Antibiotics were given only in case of signs of local infection.

\section{Statistical analysis}

Statistical analysis was performed using Prism 5 GraphPad Software. A descriptive analysis of all data was first carried out. Then a comparative study was conducted between the patients who presented with a complication and those who did not. Categorical variables were compared with chi-square analysis or Fisher exact test. Quantitative variables were compared by Mann Whitney U non parametric test. Differences between groups were considered significant if $\mathrm{p}<0.05$.

\section{Results}

Our series includes 53 patients who underwent surgery in order to improve aesthetic appearance and functional outcome of their thighs and who received a surgical treatment by medial thighplasty. Patient characteristics are summarized in Table 1.

The mean age was $47.2( \pm 11.4)$ years. The mean body mass index was $29( \pm 4.8)$ with an average weight loss before operation of $43.5 \mathrm{~kg}$ ( \pm 14.9 , ranging from 20 to $84 \mathrm{~kg}$ ). Fortyseven point two percent of our patients had a history of bariatric surgery either through laparoscopic adjustable gastric banding or by Roux-en-Y gastric bypass. Liposuction was performed in $71.7 \%$ of patients and the horizontal technique was used in $94.3 \%$ of patients. The mean weight of bilateral pannus was $760( \pm 455)$ grams. The mean drainage duration was 
$5.6( \pm 2)$ days. The mean follow up was 51.1 months ( \pm 21.6 months), ranging from 12 to 112 months. The mean length of stay was $6+/-1.8$ days.

In our series, $39.6 \%$ of patients experienced at least 1 complication. Early complications were seroma (5 cases, $9.4 \%$ ), posterior wound dehiscence (11 cases, $20.8 \%$ ) treated through healing by secondary intention, wound infection ( 3 cases, 5.7\%) and 1 case of partial skin necrosis (1.9\%). Late complication was the scar migration (9 cases, $17 \%$ ). There were no cases of large necrosis, lymphoedema, deep vein thrombosis, pulmonary embolism, nor any vulvar problems.

Comparing patients who developed a postoperative complication with those who did not, there were few statistically significant variables. Only a high massive weight loss BMI (Figure 1) and a high pre-medial thighplasty BMI (Figure 2) were found to be statistically associated with an increased postoperative complication rate $(\mathrm{p}=0.042$ and 0.044 respectively). Likewise, a low complication rate was associated with a low BMI ( $p=0.048$, Chi-square analysis, Figure 3). No difference was found regarding at in the age, the weight, the weight loss before thighplasty, BMI decrease, the history of bariatric surgery, diabetes, blood pressure, the use of liposuction, the operating duration and the vertical or horizontal approach.

\section{Discussion}

Obesity is a major public health concern in western societies. Beside medical treatments, bariatric surgery was developed for patients with class III obesity (Body Mass Index $>40$ $\mathrm{kg} / \mathrm{m}^{2}$ ). Presently, it is the best treatment for these patients to reduce mortality and morbidity [21], particularly type 2 diabetes [22], which is corrected even before weight loss [23]. With 
the spread of obesity worldwide, the number of patients operated by this kind of surgery is steadily increasing.

The effects of massive weight loss after this kind of surgery often require multiple operations to correct the redundant skin and fat excess, such as: breast reduction mammaplasty, abdominoplasty, medial thighplasty and brachioplasty. Overall management of these patients is difficult because their obesity and the consequences of bariatric surgery may generate significant psychological disorders. These disorders may explain an increased suicide rate in this population versus obese patient without bariatric surgery (2.6 vs 0.9 suicide/10 000 patients/years) [21], approximately $70 \%$ of these suicide attempts occuring in the first three years after operation [24]. It is likely that patients are not adequately preoperatively informed of the sequelae of massive weight loss and of existing solutions to treat these sequelae.

Clearly, skin laxity of the medial thigh is both an aesthetic and a functional problem possibly causing skin maceration and interfering with sexual activity, clothing and walking. Medial thighplasty has been established for several decades since it was first described by Lewis [11]. Anchoring techniques are now well described [17] which help to stabilize the results of surgery over time. In addition, it is now accepted for liposuction to be integrated to the thigh lift technique. However, no study compared in an objective manner the benefits that could provide liposuction within the same operative procedure.

We herein report one of the largest series in the literature of medial thighplasty. In our study, postoperative complication rate is comparable to those found in the literature. In our series, only pre-bariatric BMI and pre-medial thighplasty BMI were statistically found to be associated with an increased postoperative complication rate. Our analysis does not take into account the influence of one variable on another. This is to take into account in the 
interpretation of results. Pre-medial thighplasty BMI is for us the best predictive factor for postoperative complication. Thus, we propose this parameter to be taken into account in the decision to operate the patient, contrariwise to the pre-bariatric BMI that is not the current ratio on the day of consultation. Currently, this study is the only one that investigated the risk factors for complications after medial thighplasty. Our results are consistent with Arthurs et al [25] who found the same predictive risk factor on a retrospective series of 126 abdominal dermolipectomy.

In our study, patients with a BMI of less than $25 \mathrm{~kg} / \mathrm{m}^{2}$ had a null complication rate while it increased up to $57 \%$ for $\mathrm{BMI} \geq 35$ (Figure 3). This confirms the importance of BMI in the selection of patients eligible for thighplasty, but there is currently no limiting value of BMI above which it would seem unreasonable to go on surgery. Colwell et al [26] in their review of the literature suggests that patients with a BMI greater than 32 should not be operated, but their assumption does not rely on a high level of evidence. Patients should be informed that the higher the BMI, the greater the risk of complications is important. In this case they have to accept a higher risk of complications during the surgical procedure. In our opinion, based on the literature, the most important point is to get a stable weight on a period of at least 6 months before thighplasty and a stop of the tobacco consumption [26,27].

It is interesting to note that the choice of bariatric surgery does not affect the rate of complications. Indeed, there is not more complications in patients who lost weight by dieting than in those who underwent bariatric surgery. On the other hand, neither the surgical approach nor the use of liposuction does affect the results. Unlike Duff et al [28] who found the weight of resected tissue to impact complications rate in their series of 68 patients who underwent an abdominal dermolipectomy, this is not the case in our series of 53 patients for other pannus location. 
There are mainly two schools on why and when liposuction should be used in massive weight loss population [29]. Like us, some teams perform concomitant liposuction. This step should be done with careful and selective undermining of the flap. Indeed, it allows for a better mobility of the flap and achievement of skin closure without tension. Liposuction can be safely used as examplified in our series and others [30-32] if patient's weight has reached a plateau for at least of 6 months before surgery and if they dropped smocking in perioperative procedure. Another strategy is to perform liposuction six months prior to pannus removal. This can decrease morbidity of the flap associated with oedema caused by liposuction but this strategy needs 2 surgical procedures and this increases the cost of the procedure.

Limitations of this study need to be kept in mind; its retrospective design subjects it to the associated errors and biases inherent in this type of study. These data should be confirmed in a prospective study on a larger patient cohort.

\section{Conclusion}

The aim of this large retrospective study of 53 patients was to report our experience and evaluate our surgery outcomes concerning medial thighplasty in post massive weight loss. Few guidelines exist on the optimization of patient care and safety in this complex patient population. The information provided by this retrospective study complements the current data in the literature and can help surgeons to select patients eligible for surgery by medial thighplasty. We show that pre-medial thighplasty BMI should be taken into consideration for developing scoring the risk of complication in the postoperative period to select the best time for patients to go on body contouring procedure. 
Conflict of interest disclosure statement: The authors declare that they have no conflict of interests.

\section{References}

[1] Gallagher EJ, Leroith D, Karnieli E (2010) Insulin resistance in obesity as the underlying cause for the metabolic syndrome. The Mount Sinai journal of medicine, New York.;77(5):511-23.

[2] Lavie CJ, Milani RV, Ventura HO (2009) Obesity and cardiovascular disease: risk factor, paradox, and impact of weight loss. Journal of the American College of Cardiology;53(21):1925-32.

[3] Van Gaal LF, Mertens IL, De Block CE (2006) Mechanisms linking obesity with cardiovascular disease. Nature;444(7121):875-80.

[4] Montague CT, O'Rahilly S (2000) The perils of portliness: causes and consequences of visceral adiposity. Diabetes;49(6):883-8.

[5] Bochukova EG, Huang N, Keogh J, Henning E, Purmann C, Blaszczyk K, et al (2010) Large, rare chromosomal deletions associated with severe early-onset obesity. Nature;463(7281):666-70.

[6] Clement K, Vaisse C, Lahlou N, et al (1998) A mutation in the human leptin receptor gene causes obesity and pituitary dysfunction. Nature;392(6674):398-401.

[7] Emilsson V, Thorleifsson G, Zhang B, et al (2008) Genetics of gene expression and its effect on disease. Nature;452(7186):423-8. 
[8] Menzaghi C, Ercolino T, Di Paola R, et al (2002) A haplotype at the adiponectin locus is associated with obesity and other features of the insulin resistance syndrome. Diabetes;51(7):2306-12.

[9] Strawford A, Antelo F, Christiansen M, Hellerstein MK (2004) Adipose tissue triglyceride turnover, de novo lipogenesis, and cell proliferation in humans measured with 2H2O. American journal of physiology Endocrinology and metabolism;286(4):E577-88.

[10] (1992) Gastrointestinal surgery for severe obesity: National Institutes of Health Consensus Development Conference Statement. Am J Clin Nutr;55:Suppl 2:615S-619S

[11] Lewis JR (1957) The thigh lift The Journal of the International College of Surgeons;27(3):330-4.

[12] Lewis JR (1966) Correction of ptosis of the thighs: the thigh lift. Plastic and reconstructive surgery;37(6):494-8.

[13] Le Louarn C, Pascal JF (2004) [Internal faces lifting legs complications]. Annales de chirurgie plastique et esthetique;49(6):610-3.

[14] Schultz RC, Feinberg LA (1979) Medial thigh lift. Annals of plastic surgery;2(5):40410.

[15] Vilain R, Dardour JC (1986) Aesthetic surgery of the medial thigh. Annals of plastic surgery;17(3):176-83.

[16] Le Louarn C, Pascal JF (2004) The concentric medial thigh lift. Aesthetic plastic surgery;28(1):20-3.

[17] Lockwood TE (1988) Fascial anchoring technique in medial thigh lifts. Plastic and reconstructive surgery;82(2):299-304.

[18] Mathes DW, Kenkel JM (2008) Current concepts in medial thighplasty. Clinics in plastic surgery;35(1):151-63. 
[19] Labardi L, Gentile P, Gigliotti S, et al (2012) Medial thighplasty: horizontal and vertical procedures after massive weight loss. Journal of cutaneous and aesthetic surgery;5(1):20-5.

[20] Kenkel JM, Eaves FF (2008) Medial thigh lift. Plastic and reconstructive surgery;122(2):621-2.

[21] Adams TD, Gress RE, Smith SC, et al (2007) Long-term mortality after gastric bypass surgery. The New England journal of medicine;357(8):753-61.

[22] Buchwald H, Estok R, Fahrbach K, et al (2009) Weight and type 2 diabetes after bariatric surgery: systematic review and meta-analysis. The American journal of medicine;122(3):248-56 e5.

[23] Rubino F, Gagner M, Gentileschi P, et al (2004) The early effect of the Roux-en-Y gastric bypass on hormones involved in body weight regulation and glucose metabolism. Annals of Surgery;240(2):236-42.

[24] Tindle HA, Omalu B, Courcoulas A, et al (2010) Risk of suicide after long-term follow-up from bariatric surgery. The American journal of medicine;123(11):1036-42.

[25] Arthurs ZM, Cuadrado D, Sohn V, et al (2007) Post-bariatric panniculectomy: prepanniculectomy body mass index impacts the complication profile. American journal of surgery;193(5):567-70; discussion 70 .

[26] Colwell AS, Borud LJ (2008) Optimization of patient safety in postbariatric body contouring: a current review. Aesthetic Surgery Journal;28(4):437-42.

[27] van der Beek ES, van der Molen AM, van Ramshorst B (2011) Complications after body contouring surgery in post-bariatric patients: the importance of a stable weight close to normal. Obesity facts;4(1):61-6.

[28] Duff CG, Aslam S, Griffiths RW (2003) Fleur-de-Lys abdominoplasty--a consecutive case series. British journal of plastic surgery;56(6):557-66. 
[29] Shrivastava P, Aggarwal A, Khazanchi RK (2008) Body contouring surgery in a massive weight loss patient: an overview. Indian J Plast Surg; 41:S114-S129.

[30] Gusenoff JA, Coon BA, Rubin JP (2008) Brachioplasty and concomitant procedures after massive weight loss: a statistical analysis from a prospective registry. Plastic and reconstructive surgery;122(2):595-603

[31] Kolker AR, Xipoleas GD (2011) The circumferential thigh lift and vertical extension circumferential thigh lift: maximizing aesthetics and safety in lower extremity contouring. Annals of plastic surgery; 66(5):452-6.

[32] Kolker AR, Lampert JA (2009) Maximizing aesthetics and safety in circumferentialincision lower body lift with selective undermining and liposuction. Annals of plastic surgery; 62(5):544-8.

\section{Figure Legend:}

Figure 1 Pre-massive weight loss BMI risk factor.

The values for Body Mass Index in the $\mathrm{Y}$ axis are in $\mathrm{kg} / \mathrm{m}^{2}$ and were analysed with Mann Whitney U test. Mean is depicted by a scale bar. 


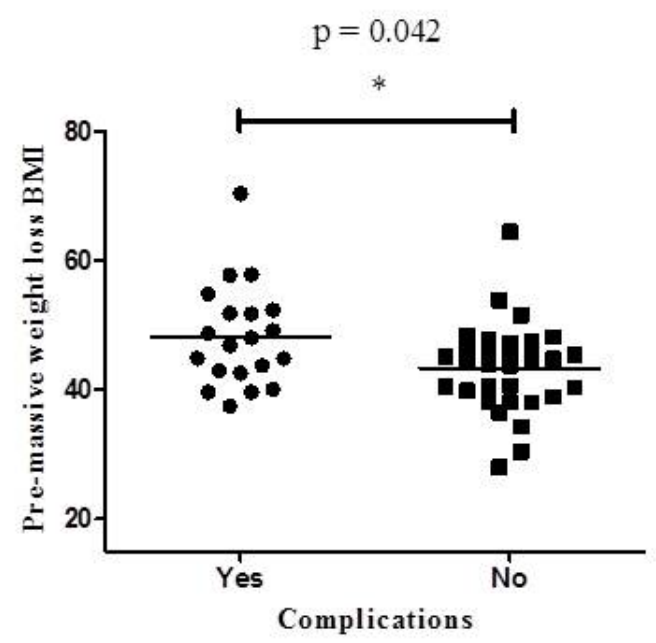

Figure 1. Pre-massive weight loss BMI risk factor.

Figure 2 Pre-medial thighplasty BMI risk factor.

The values for Body Mass Index in the $\mathrm{Y}$ axis are in $\mathrm{kg} / \mathrm{m}^{2}$ and were analysed with Mann Whitney U test. Mean is depicted by a scale bar. 


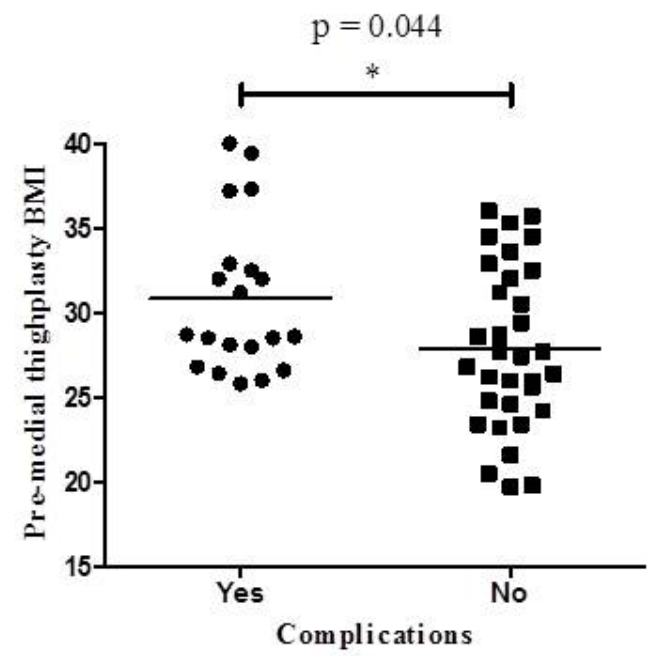

Figure 2. Pre-medial thighplasty BMI risk factor.

Figure 3 BMI effect on postoperative complications.

Overall postoperative complication rate is expressed as a number of patients in the Y. The Body Mass Index in the $\mathrm{X}$ axis is in $\mathrm{kg} / \mathrm{m}^{2}$ and differences between groups were analysed by the Chi-square test. 


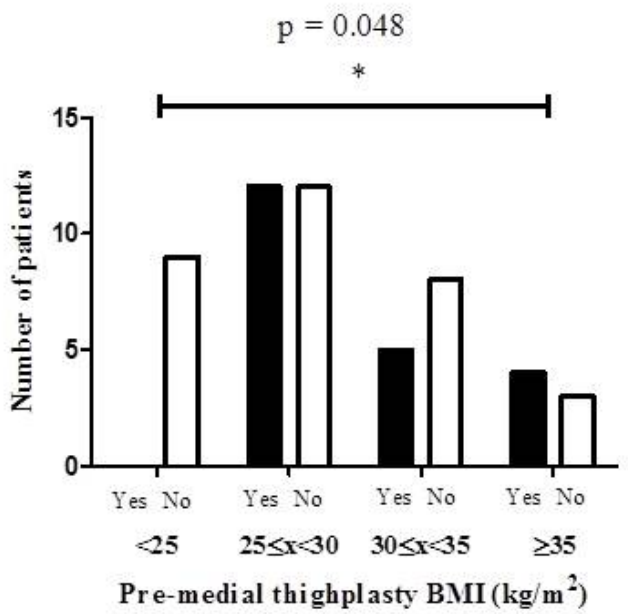

Figure 3. BMI effect on postoperative complications.

\section{Tables}


Table 1 - Cohort demographics

\begin{tabular}{lc}
\hline Variable & Mean \pm SD/n (\%) \\
\hline Number of patients & 53 \\
Age & $47 \pm 11$ \\
Gender (female) & $53(100 \%)$ \\
Pre-massive weight loss BMI & $44,8 \pm 8,3$ \\
Weight loss (Kg) & $43,5 \pm 14,9$ \\
Pre-medial thighplasty surgery BMI & $29,0 \pm 4,8$ \\
Delta BMI & $15,8 \pm 6,7$ \\
history of bariatric surgery & $25(47,2 \%)$ \\
peroperative liposuction & $39(71,7 \%)$ \\
Any complication & $33(60,4 \%)$ \\
Complications & $21(39,6 \%)$ \\
\multicolumn{1}{c}{ Seroma } & $5(9,4 \%)$ \\
$\quad$ wound dehiscence & $11(20,8 \%)$ \\
$\quad$ wound infection & $3(5,7 \%)$ \\
$\quad$ scar migration & $9(17 \%)$ \\
$\quad$ partial skin necrosis & $1(1,9 \%)$ \\
\hline
\end{tabular}

The values for categorical variables are numbers and percentage and the values for quantitative variables are mean $+/-\mathrm{SD}$.

Table 2 - Statistical analysis

\begin{tabular}{lccc}
\hline & complications & no complications & $\mathrm{p}$ \\
\hline Age & $47,7 \pm 10,0$ & $47,2 \pm 12,4$ & 0,961 \\
Weight & $79,1 \pm 9,8$ & $73,4 \pm 12,6$ & 0,066 \\
Pre-massive weight loss BMI & $48,3 \pm 7,9$ & $43,4 \pm 6,8$ & 0,042 \\
Weight loss (Kg) & $44,9 \pm 16,1$ & $40,4 \pm 17,1$ & 0,651 \\
Pre-medial thighplasty surgery BMI & $30,8 \pm 4,5$ & $27,9 \pm 4,8$ & 0,044 \\
Delta BMI & $17,5 \pm 6,2$ & $14,8 \pm 6,9$ & 0,275 \\
history of bariatric surgery & 12 & 13 & 0,168 \\
history of diabetes & 5 & 5 & 0,475 \\
history of high pressure blood & 4 & 8 & 1,000 \\
horizontal approach & 20 & 30 & 0,282 \\
liposuction & 15 & 24 & 1,000 \\
weight of skin resection (grams) & $844,0 \pm 491$ & $657,0 \pm 400$ & 0,393 \\
operative time (minutes) & $111,5 \pm 22$ & $107,3 \pm 27$ & 0,492 \\
\hline
\end{tabular}

The values for categorical variables are numbers, statistical analysis was performed by the Fisher exact test. The values for quantitative variables are mean +/- SD and were analysed by the Mann Whitney test. 